\title{
Grazing and virus-induced mortality of microbial populations before and during the onset of annual hypoxia in Lake Erie
}

\author{
Christopher J. Gobler ${ }^{1, *}$, Timothy W. Davis ${ }^{1}$, Sarah N. Deonarine ${ }^{1}$, Matthew A. Saxton ${ }^{2}$, \\ Peter J. Lavrentyev ${ }^{3}$, Frank J. Jochem ${ }^{4}$, Steven W. Wilhelm² \\ ${ }^{1}$ School of Marine and Atmospheric Sciences, Stony Brook University, Southampton, New York 11968, USA \\ ${ }^{2}$ Department of Microbiology, The University of Tennessee, Knoxville, Tennessee 37996, USA \\ ${ }^{3}$ Department of Biology, The University of Akron, Akron, Ohio 44325, USA \\ ${ }^{4}$ Marine Biology Program, Florida International University, North Miami, Florida 33181, USA
}

\begin{abstract}
Lake Erie is the most productive of the North American Great Lakes and experiences annual periods of hypolimnetic hypoxia with unknown consequences for the microbial food web. We established the abundances and mortality rates of microbes in Lake Erie during thermal stratification and determined how they varied with changes in bottom-water dissolved oxygen concentrations. The microbial plankton community (heterotrophic bacteria, Cyanobacteria, eukaryotic phytoplankton, nanozooplankton, microzooplankton) was quantified in surface and bottom waters along with measurements of herbivory and bacterivory rates on eukaryotic and prokaryotic picoplankton and rates of viral lysis of bacteria. High rates of grazing mortality of prokaryotic picoplankton $\left(1.4 \pm 0.6 \mathrm{~d}^{-1}\right)$ and eukaryotic algae $\left(0.66 \pm 0.27 \mathrm{~d}^{-1}\right)$ and significant correlations between microzooplankton abundances and all picoplankton populations quantified demonstrated the strong impacts of grazing on Lake Erie picoplanktonic communities. Microbial herbivory accounted for half of total phytoplankton mortality per day. Bacterivory and viral lysis turned over $85 \%$ of the heterotrophic bacterial community each day. During the onset of hypolimnetic hypoxia, abundances of ciliates and rotifers decreased significantly and herbivory was undetectable. Concurrently, bacterivory persisted at rates equal to those found in shallower oxygenated waters, and abundances of heterotrophic nanoflagellates did not change significantly. These results suggest that, during hypoxia events in Lake Erie, herbivory by microzooplankton is disrupted, but bacterivory by heterotrophic nanoflagellates persists. Finally, rates of viral lysis of heterotrophic bacteria were higher in the hypolimnion than in surface waters, suggesting that increased viral lysis may enhance regeneration of organic matter in bottom waters during hypoxic events.
\end{abstract}

KEY WORDS: Microbial mortality · Great Lakes · Grazing · Viruses $\cdot$ Hypoxia

\section{INTRODUCTION}

The North American Laurentian Great Lakes contain ca. $20 \%$ of Earth's fresh water, making them a vital global resource. Lake Erie is the shallowest, most productive, most anthropogenically influenced, and socioeconomically important among them. Because of its physical morphology and biological activity, the hypolimnion of the central basin experiences a period of hypoxia $\left(<3 \mathrm{mg} \mathrm{O}_{2} \mathrm{l}^{-1}\right)$ each year during late summer-early fall (Charlton 1980, Wilhelm et al. 2006). The implications of these hypoxic events are numerous and include potential impacts on fisheries yields and recruitment, and the development of niche space for novel members of the planktonic food web (Wilhelm et al. 2006). Previous studies in Lake Erie have elucidated individual parts of the pelagic food web, bacterial abundance and production (Hwang \& Heath 1997b, 
1999, DeBruyn et al. 2004), autotrophic plankton growth rates (Twiss et al. 1996) and mesozooplankton abundance and production (Johanssen et al. 2000). However, the impacts of hypoxia on the microbial food web in Lake Erie are currently unknown.

Estimates of the overall importance of the microbial food web (i.e. how much energy is channelled through its component pathways) vary greatly and are dependent on the system in question. Phototrophic (Fahnenstiel et al. 1998) and heterotrophic (Scavia \& Laird 1987) picoplankton (i.e. 0.2 to $2.0 \mu \mathrm{m}$ ) constitute the majority of primary and secondary producers in the Great Lakes. The high ratio of bacterial production to primary production often observed in these lakes can be explained by allochthonous inputs of organic carbon (Scavia et al. 1988). Nanoplankton- (2 to $20 \mu \mathrm{m}$ ) and microplankton-sized (20 to $200 \mu \mathrm{m}$ ) grazers (mostly protists) hold key positions in most aquatic food webs as their grazing can regulate biomass levels of primary and secondary producers, and this activity in turn provides upper trophic levels with substantial amounts of energy (Calbet \& Landry 2004). Since the majority of plankton biomass in Lake Erie is derived from picoplankton (Fahnenstiel et al. 1998) and since mesozooplankton $(>200 \mu \mathrm{m})$ cannot effectively consume such small cells (Hwang \& Heath 1999), microzooplankton and heterotrophic nanoflagellates are likely the primary consumers of pelagic microbial biomass in this system. Previous studies in offshore waters of Lake Erie have shown that ciliates and other heterotrophic protists are abundant components of the pelagic food web (Hwang \& Heath 1997a, Fahnenstiel et al. 1998); they control bacterial production (Hwang \& Heath 1997b, 1999) and graze heavily on picophytoplankton (Twiss et al. 1996). However, simultaneous measurements of microbial bacterivory and herbivory rates in Lake Erie have been limited to nearshore environments (Lavrentyev et al. 2004), and the effects of hypolimnetic hypoxia on these key processes remain unknown.

Viruses also influence microbial dynamics in Lake Erie. Up to $20 \%$ of the bacterial mortality in Lake Erie can be due to viral activity (Wilhelm \& Smith 2000). In some lake hypoxic zones, viruses are the most important mechanism of microbial mortality as they are typically insensitive to water column oxygen levels (Weinbauer \& Höfle 1998, Colombet et al. 2006). Hence, virus-induced mortality may become even more important in Lake Erie during the onset of hypoxia. Although viruses are the most abundant and most rapidly reproducing biological entities in Lake Erie (DeBruyn et al. 2004), their precise role in food web dynamics during the onset of seasonal hypoxia is currently unknown.
We sought to establish how Great Lakes microbial communities and their mortality rates varied with changes in bottom dissolved oxygen during thermal stratification. The abundances of the microbial plankton including heterotrophic bacteria, picocyanobacteria, eukaryotic phytoplankton, heterotrophic nanoflagellates (HNF), and microzooplankton (ciliates and rotifers) in surface and bottom waters of Lake Erie were quantified concurrently with measurements of rates of grazing mortality for eukaryotic and prokaryotic picoplankton and viral lysis of bacteria. Measurements of dissolved oxygen in the hypolimnion (range 1.7 to $10 \mathrm{mg} \mathrm{l}^{-1}$ ) allowed us to assess variation in plankton abundances and mortality rates in relation to oxygen levels. To our knowledge, this is the first Great Lakes study to combine measurements of microbial grazing mortality and viral lysis rates and consider them in relation to hypolimnetic oxygen depletion.

\section{MATERIALS AND METHODS}

Eight stations in the central basin of Lake Erie were visited by the RV 'Lake Guardian' in early August 2005 - Stns m8 $\left(41^{\circ} 42^{\prime} 47^{\prime \prime} \mathrm{N}, 82^{\circ} 21^{\prime} 87^{\prime \prime} \mathrm{W}\right)$, E73 $\left(41^{\circ} 58^{\prime} 65^{\prime \prime} \mathrm{N}, 81^{\circ} 45^{\prime} 42^{\prime \prime} \mathrm{W}\right)$, E78 $\left(42^{\circ} 07^{\prime} 00^{\prime \prime} \mathrm{N}\right.$,

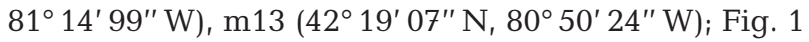
- and on the Canadian Coast Guard Vessel 'Limnos' during late August 2005-Stns 961 (41 $54^{\circ} 34^{\prime \prime} \mathrm{N}$, $\left.82^{\circ} 11^{\prime} 04^{\prime \prime} \mathrm{W}\right), 84 \quad\left(41^{\circ} 56^{\prime} 13^{\prime \prime} \mathrm{N}, 81^{\circ} 39^{\prime} 06^{\prime \prime} \mathrm{W}\right), 888$ $\left(42^{\circ} 06^{\prime} 39^{\prime \prime} \mathrm{N}, \quad 81^{\circ} 34^{\prime} 24^{\prime \prime} \mathrm{W}\right), \quad 953 \quad\left(42^{\circ} 12^{\prime} 33^{\prime \prime} \mathrm{N}\right.$, $\left.81^{\circ} 26^{\prime} 30^{\prime \prime} \mathrm{W}\right)$; Fig. 1. Station names correspond to those previously established by US EPA (United States Environmental Protection Agency) and Environment Canada. CTD arrays were used to record temperature and oxygen profiles and to assess the water column structure. These dissolved oxygen measurements were subsequently confirmed by measurement (using a hand-held YSI BOD probe Model 58) of concentrations in Niskin bottles closed at various depths. Water from each station was collected from within (1 to $10 \mathrm{~m}$ ) and below (12 to $25 \mathrm{~m}$ ) the epilimnion using a rosette cast. Size-fractionated chlorophyll a (chl a) was determined

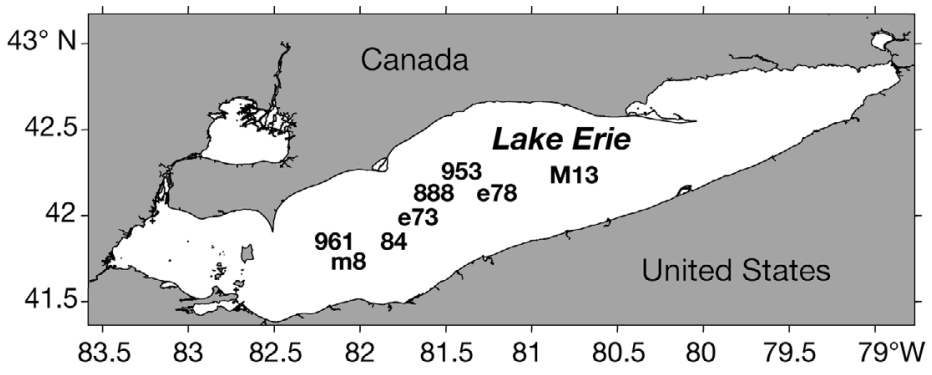

Fig. 1. Stations sampled in Lake Erie during August 2005 
from parallel triplicate filtrations of samples collected on $0.2,2$, and $20 \mu \mathrm{m}$ nominal pore-size polycarbonate filters (47 mm diameter; Millipore) after extraction (ca. $24 \mathrm{~h},-20^{\circ} \mathrm{C}$ ) in $90 \%$ acetone. Chl a retained on the different filters was quantified with a Turner Designs TD700 fluorometer using a non-acidification protocol (Welschmeyer 1994).

Phytoplankton communities and heterotrophic bacteria were analyzed by flow cytometry in samples preserved in $1 \%$ formalin and flash-frozen in liquid nitrogen. Abundances of heterotrophic bacteria (stained with SYBR Green I, Jochem 2001), phycoerythrincontaining picocyanobacteria and photosynthetic picoeukaryotes were determined with a FACSort $\left(\right.$ BD $\left.^{\circledR}\right)$ flow cytometer using fluorescence patterns and particle size from side angle light scatter (Olson el al. 1991). Heterotrophic nanoflagellates (here 1 to $10 \mu \mathrm{m}$, HNF and plastidic forms) were preserved with glutaraldehyde $(2 \% \mathrm{v} / \mathrm{v}$, final) concentrated onto $0.2 \mu \mathrm{m}$ black polycarbonate membrane filters, stained with DAPI, mounted on microscope slides and stored frozen. In the laboratory, they were counted under an epifluorescent microscope $(1000 \times$ magnification) using a dual-band UV/green excitation filter set (Sherr et al. 1993). At least 200 cells filter $^{-1}$ were enumerated. Only aplastidic HNF are reported here. Samples were also examined under an epifluorescence microscope to confirm the identification of picoplankton made via flow cytometry. Within water column samples, two classes of Cyanobacteria were quantified. One group consisted of small, unicellular Cyanobacteria that contained phycoerythrin and resembled Synechococcus sp., while the second population consisted of coccoid, phycoerythrin-containing Cyanobacteria; cells of the second type were slightly larger (ca. $1 \mu \mathrm{m}$.) than Synechococcus-like Cyanobacteria and occurred in aggregates of 2 or more cells. This second group of picocyanobacteria was quantified in the water column but not in experimental samples.

Duplicate microplankton samples were analyzed according to Hasle (1978) to identify and quantify the major taxonomic categories of microzooplankton (ciliates and rotifers). Samples $(200 \mathrm{ml})$ obtained from the upper mixed layer ( 1 to $5 \mathrm{~m}$ ) and from the hypolimnion (15 to $20 \mathrm{~m}$ ) were preserved with acid Lugol's solution (5\% final concentration) and counted using an inverted microscope. A minimum of 200 organisms or 100 grids were counted per $50 \mathrm{ml}$ sample, which often constituted the entire settled well.

Dilution experiments were performed to determine the impact of grazing on microbial mortality. Experiments involved four treatments $(100,70,40$, and $15 \%$ whole lake water) each performed in triplicate 1.21 bottles. An additional experimental bottle was filled with $0.2 \mu \mathrm{m}$ filtered lake water to verify that the $0.2 \mu \mathrm{m}$ filters removed all particles. Whole water collected for grazing experiments was gravity-filtered through inline, acid-cleaned $200 \mu \mathrm{m}$ screening $\left(\right.$ Nytex $\left.^{\mathrm{TM}}\right)$, whereas filtered water was gravity filtered through acidcleaned, $0.2 \mu \mathrm{m}$ filter capsules (Pall) with vents that eliminated bubbling of water as it entered the capsules. Measurements of nutrients in the filtrate were not significantly different from those made in water gently filtered through combusted glass fiber filters ( $p>0.05, t$-test), indicating that the capsule filtering process did not add or remove nutrients (ammonium, orthophosphate, dissolved organic nitrogen and phosphorus). Levels of oxygen in bottles filled for experiments (measured with a YSI BOD probe model 58) were never significantly different from levels measured with the oxygen sensor on the shipboard rosette at the depth of water collection ( $p>0.05, t$-test). All bottles were amended with nitrate $(20 \mu \mathrm{M})$, silicate $(20 \mu \mathrm{M})$, and orthophosphate $(1.25 \mu \mathrm{M})$ to assure nutrient-replete growth of phytoplankton (Landry et al. 1995). An additional triplicate set of experimental bottles containing $100 \%$ whole lake water without nutrient amendment was used to examine the effect of nutrient additions (Landry et al. 1995). During the period of incubation, bottles were placed in incubators maintained at temperatures matching levels found at the point of collection. Bottles were also shielded with neutral density screening to reduce light to ambient levels at collection depth. Samples for chl a analysis and flow cytometric analysis were obtained from each of the experimental bottles after $24 \mathrm{~h}$ incubation.

Net growth rates of heterotrophic bacteria, picocyanobacteria (i.e. Synechococcus spp.), photosynthetic picoeukaryotes, and the total phytoplankton community (TPC, based on chl a) were determined using initial and final cell abundance or chl a concentrations. Growth rates were calculated as:

$$
k=\left[\ln \left(B_{t} / B_{0}\right)\right] / t
$$

where $k$ is the net growth rate, $B_{t}$ is the biomass or cell abundance at $t=1 \mathrm{~d}, B_{0}$ is the biomass or cell abundance at $t=0 \mathrm{~d}$, and $t$ is the duration (d) of the experiment. Mortality rates in the dilution experiments were determined from linear regressions of net (apparent) growth rate versus the proportion of whole lake water $(0.15,0.40,0.70,1.0)$. The negative slope of this regression yielded mortality rate, which was assumed to result from grazing, and the $y$-intercept (corrected for the impact of nutrient addition on growth rates in whole water) was equivalent to the cellular growth rate in the absence of predators (Landry et al. 1995). The standing stock percentage (biomass or cell densities) of each microbial population consumed per day was calculated according to Reckermann \& Veldhuis (1997). 
Transmission electron microscopy (TEM) was employed to examine the percentage of visibly infected cells (\%VIC) in the native bacterial community and to estimate the abundance of viruses released per bacterium lysed (average burst size). Duplicate whole water samples $(40 \mathrm{ml})$ preserved with glutaraldehyde $(2 \% \mathrm{v} / \mathrm{v}$, final $)$ and stored in the dark at $4{ }^{\circ} \mathrm{C}$ in sterile polypropylene tubes were collected by centrifugation $(1.25 \mathrm{~h}$ at $16600 \times g)$ onto carbon-coated collodion films over 400-mesh electron microscope grids. Grids were subsequently rinsed, stained with $0.75 \%$ uranyl formate, and rinsed again. The \%VIC and burst size were determined by TEM as previously described (Weinbauer \& Suttle 1996). Samples were viewed at the University of Tennessee Microscopic Analysis Facility with a Hitachi H-800 TEM at an accelerating voltage of $100 \mathrm{keV}$. For each sample, 2 grids were prepared, and 1000 bacterial cells were examined. Burst size was defined as the average number of viral particles in all visibly infected cells. This represents the minimum burst size, as cells may have developed further particles prior to lysis (Weinbauer et al. 2002).

Viruses inside bacterial cells become visible during the last $\sim 10 \%$ of the lytic cycle (Proctor et al. 1993). To account for this, conversion factors (3.7 to 7.17 ) were multiplied by the \%VIC to estimate the percentage of infected cells (\%IC). This provides a range (as a percentage of cells) of the entire population that is infected. The fraction of bacterial cell mortality attributable to viral lysis (FMVL) has been determined previously using the factor-of-2 rule (Proctor et al. 1993). However, since a proportion of the infected population is also removed by grazers, \% IC and percentage mortality due to viral lysis (\%MVL) were determined according to Binder (1999), whereby bacterial infection (also as percentages of the total bacterial population) is derived from the following:

$$
\begin{gathered}
\% \mathrm{IC}=7.1 \times \% \mathrm{VIC}-22.5 \times \% \mathrm{VIC}^{2} \\
\text { FMVL }=\left(\% \mathrm{IC}+0.6 \times \% \mathrm{IC}^{2}\right) /(1-1.2 \times \% \mathrm{IC})
\end{gathered}
$$

Finally, the diel percentage of bacterial cell mortality attributable to viral lysis was determined by multiplying bacterial growth rates per day (derived from dilution experiment, see above) by FMVL.

Comparisons among variables (e.g. microbial groups) were made with 1-way ANOVAs followed by Tukey's multiple comparison tests or appropriate nonparametric tests (e.g. Mann-Whitney rank sum test). Comparison of variables between the epilimnion and hypolimnion were made with $t$-tests. The degree to which individual variables were correlated was evaluated with a Spearman's Rank Order Correlation Matrix. In all cases, a p level of 0.05 was applied to identify statistically significant differences or correlations.

\section{RESULTS}

\section{Microbial dynamics}

On all sampling occasions, the water column of Lake Erie had strong thermal stratification, with surface temperatures (5 m: 23 to $26^{\circ} \mathrm{C}$, Table 1 ) typically at least $10^{\circ} \mathrm{C}$ warmer than bottom waters (20 m: 7.1 to $11^{\circ} \mathrm{C}$, Table 1). Stn 84 is shown in Fig. 2 as an example. Despite cooler hypolimnion temperatures, levels of dissolved oxygen in bottom waters were almost always substantially lower than in the surface water (Table 1, Fig. 2). Bottom oxygen levels during early August (4.2 to $10 \mathrm{mg} \mathrm{l}^{-1}$; Table 1, Fig. 2) were substantially higher than in late August when 3 stations had dissolved oxygen levels $<3 \mathrm{mg} \mathrm{l}^{-1}$ (Stns 961, 84, 88: 1.7 to $2.7 \mathrm{mg} \mathrm{l}^{-1}$; Table 1, Fig. 1) and a fourth station was slightly more oxygenated (Stn 953: $3.7 \mathrm{mg} \mathrm{l}^{-1}$; Table 1, Fig. 1).

Eukaryotic and prokaryotic (heteroand autotrophic) picoplankton followed similar trends by depth, with abundances generally higher in surface waters and decreasing toward the bottom. Stn 84 is shown in Fig. 2 as an example. Surface chl a concentrations
Fig. 2. Vertical depth profiles of temperature $\left(T,{ }^{\circ} \mathrm{C}\right)$, dissolved oxygen $\left(\mathrm{mg} \mathrm{l}^{-1}\right)$, chl a $\left(\mu \mathrm{g}^{-1}\right)$, eukaryotic phytoplankton, unicellular Cyanobacteria containing phycoerythrin and resembling Synechococcus sp., coccoid phycoerythrincontainig Cyanobacteria, and heterotrophic bacteria at Stn 84 in Lake Erie, August 2005. Error bars are omitted for clarity. Relative SD of measurements was $\leq 10 \%$ 


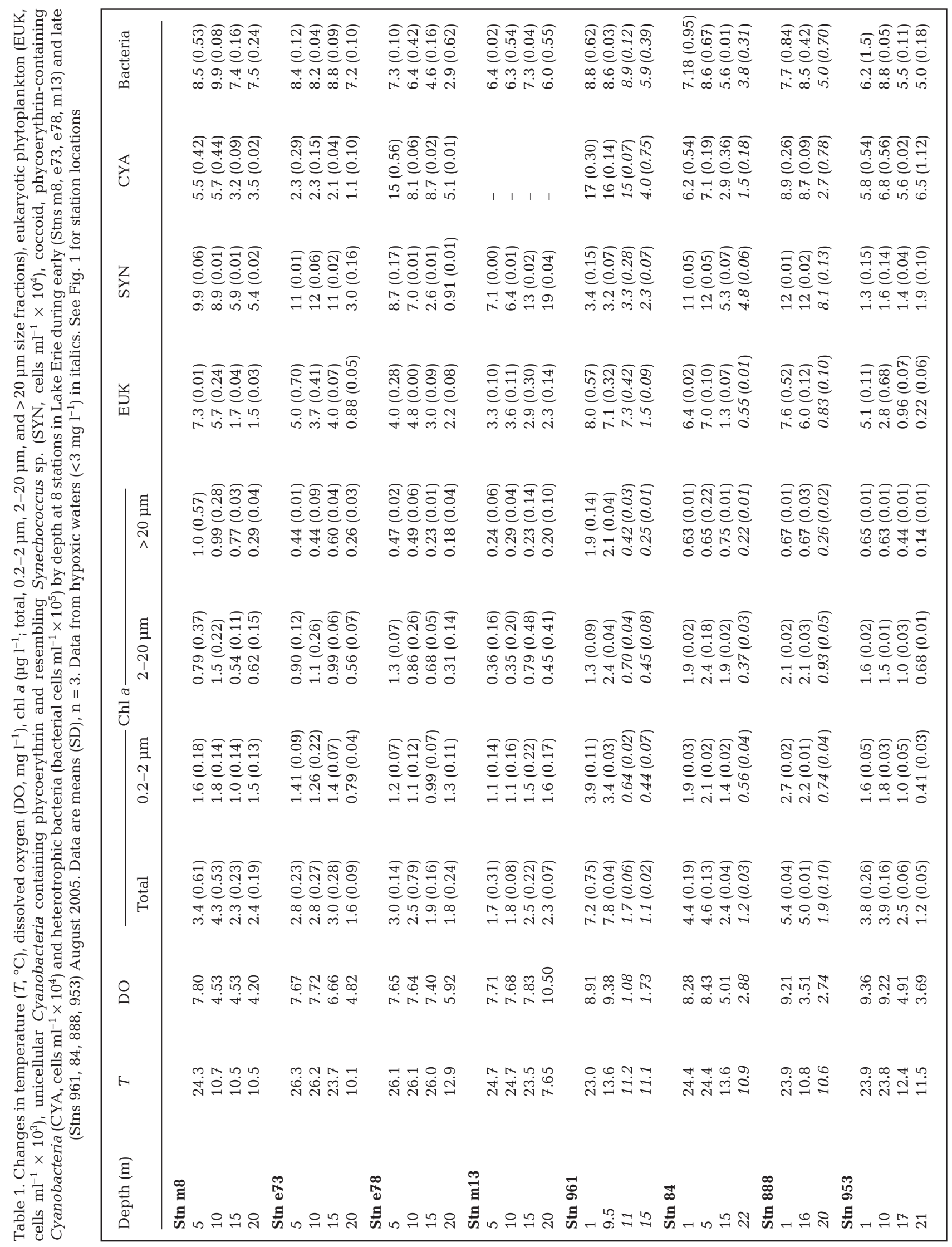


were slightly higher during late August (3.8 to $7.2 \mu \mathrm{g}$ $\mathrm{l}^{-1}$ ) than in early August (1.7 to $3.4 \mathrm{\mu g} \mathrm{l}^{-1}$ ), and were always lower in the hypolimnion (1.0 to $3.0 \mu \mathrm{g} \mathrm{l}^{-1}$, Table 1). Bacteria were numerically dominant among the picoplankton, followed by picocyanobacteria and eukaryotic algae (Table 1, Fig. 2). Abundances and vertical distributions of these groups were similar among stations, with generally higher levels in surface waters and lower densities in the hypolimnion (Table 1, Fig. 2). Abundances of heterotrophic bac-

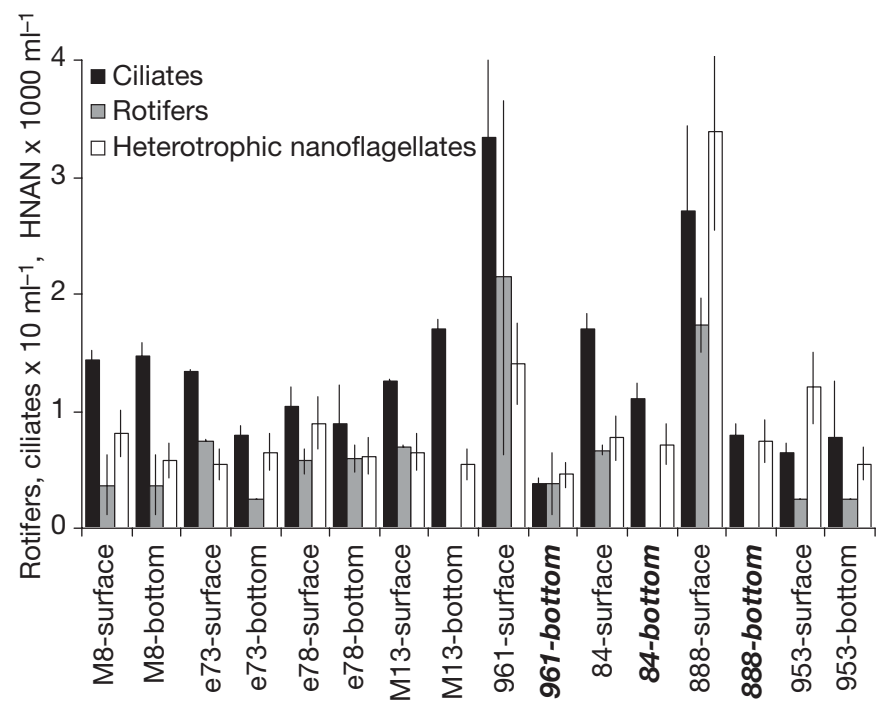

Fig. 3. Densities of ciliates, rotifers and heterotrophic nanoflagellates (HNAN) in surface and bottom waters of Lake Erie during August 2005. Data are means $\pm \mathrm{SD}, \mathrm{n}=3$. Samples $\mathrm{m} 8$, E73, E78 and m13 were collected in early August; samples 961, 84,888 and 953 were collected in late August. Hypoxic samples are bold and italicized

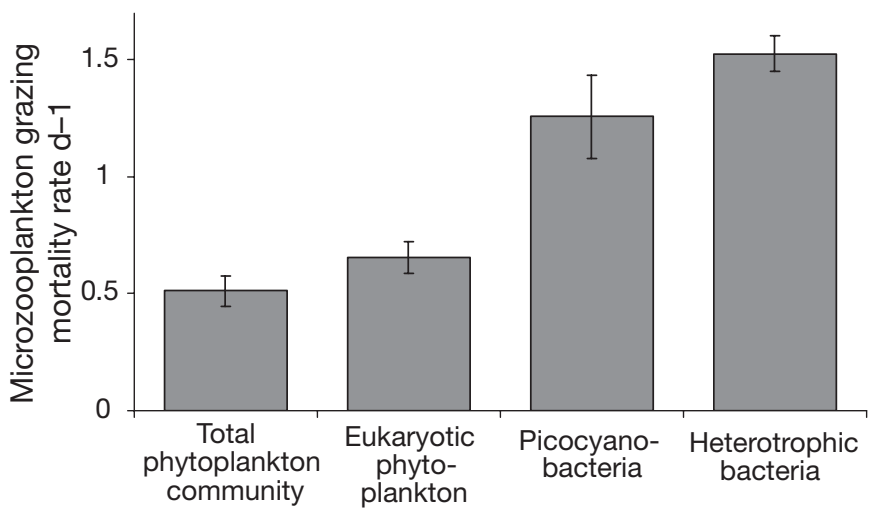

Fig. 4. Grazing mortality rates of the total phytoplankton community (based on chl a), eukaryotic phytoplankton, unicellular Cyanobacteria (contain phycoerythrin and resembling Synechococcus sp., viz. picocyanobacteria), and heterotrophic bacteria in surface and bottom waters (combined) of Lake Erie during August 2005. Means \pm SD are shown $(n=16$ for cyanobacteria, $\mathrm{n}=15$ heterotrophic bacteria, $\mathrm{n}=13$ for total phytoplankton community, $\mathrm{n}=11$ for eukaryotes) teria, Synechococcus-like Cyanobacteria, coccoid Cyanobacteria and eukaryotic algae ranged, respectively, from 6.2 to $8.5 \times 10^{5} \mathrm{ml}^{-1}, 0.7$ to $12 \times 10^{4} \mathrm{ml}^{-1}$, 0.0 to $1.2 \times 10^{5} \mathrm{ml}^{-1}$, and 3.3 to $8.0 \times 10^{3} \mathrm{ml}^{-1}$ in surface waters and 0.9 to $8.1 \times 10^{5} \mathrm{ml}^{-1}$, 0.9 to $5.4 \times 10^{4} \mathrm{ml}^{-1}$, 0.0 to $5.1 \times 10^{4} \mathrm{ml}^{-1}$, and 0.2 to $2.3 \times 10^{3} \mathrm{ml}^{-1}$ in the hypolimnion (Table 1).

While ciliate and rotifer abundances were similar in the epi- and hypolimnion in early August $(12 \pm 3$ and $0.5 \pm 0.2$ ind. $\mathrm{ml}^{-1}$, respectively; Fig. 3), abundances of both populations were significantly higher in the epilimnion $\left(27 \pm 4.4\right.$ ciliates $\mathrm{ml}^{-1}, 0.7$ rotifers $\left.\mathrm{ml}^{-1}\right)$ compared to the hypolimnion $\left(7.2 \pm 1.4\right.$ ciliates $\mathrm{ml}^{-1}, 0.1$ rotifers $\mathrm{ml}^{-1}$ ) during late August at Stns 961, 84, and 888 (Fig. $3 ; \mathrm{p}<0.05, t$-test). At the fourth late August station (953), surface and bottom abundances were similar. Oligotrichs and choreotrichs were numerically dominant among the ciliates. In contrast to ciliates and rotifers, heterotrophic nanoflagellate abundances were less variable (grand mean $=910 \pm 180$ ind. $\mathrm{ml}^{-1}$, Fig. 3) and did not differ significantly between surface and bottom waters ( $p>0.05$, Fig. 3).

\section{Microbial growth and grazing mortality}

Substantial rates of grazing mortality were detected for all microbial groups examined. Microbial growth rates and grazing mortality rates were generally higher for prokaryotic plankton than eukaryotic picophytoplankton. For example, across the entire study, growth rates of Synechococcus-like picocyanobacteria and heterotrophic bacteria were significantly higher $\left(1.7 \pm 0.3\right.$ and $1.2 \pm 0.1 \mathrm{~d}^{-1}$, respectively) than those of the total phytoplankton community (based on chl a) and eukaryotic phytoplankton $(0.43 \pm 0.08$ and $0.79 \pm$ $0.14 \mathrm{~d}^{-1}$, respectively (Tukey's test, $\mathrm{p}<0.01$ for all) (Table 2). Similarly, grazing mortality rates for Synechococcus-like picocyanobacteria and heterotrophic bacteria were significantly higher $(1.3 \pm 0.2$ and $1.5 \pm$ $0.1 \mathrm{~d}^{-1}$, respectively) than those of the total phytoplankton community and eukaryotic phytoplankton $\left(0.51 \pm 0.07\right.$ and $0.66 \pm 0.08 \mathrm{~d}^{-1}$, respectively; Tukey's test; $\mathrm{p}<0.001$ for all) (Fig. 4). Across experiments, grazers consumed $40 \pm 5.2$ and $48 \pm 5.1 \%$ of the total phytoplankton community and eukaryotic phytoplankton $\mathrm{d}^{-1}$, respectively, and $71 \pm 10$ and $78 \pm 3.8 \%$ of the picocyanobacteria and heterotrophic bacteria $\mathrm{d}^{-1}$, respectively.

Grazing rates on individual microbial groups did not differ significantly between early and late August or between surface and bottom waters in experiments where grazing was successfully measured $(p>0.05, t-$ test). However, there were several incidences when grazing rates were undetectable using the dilution 


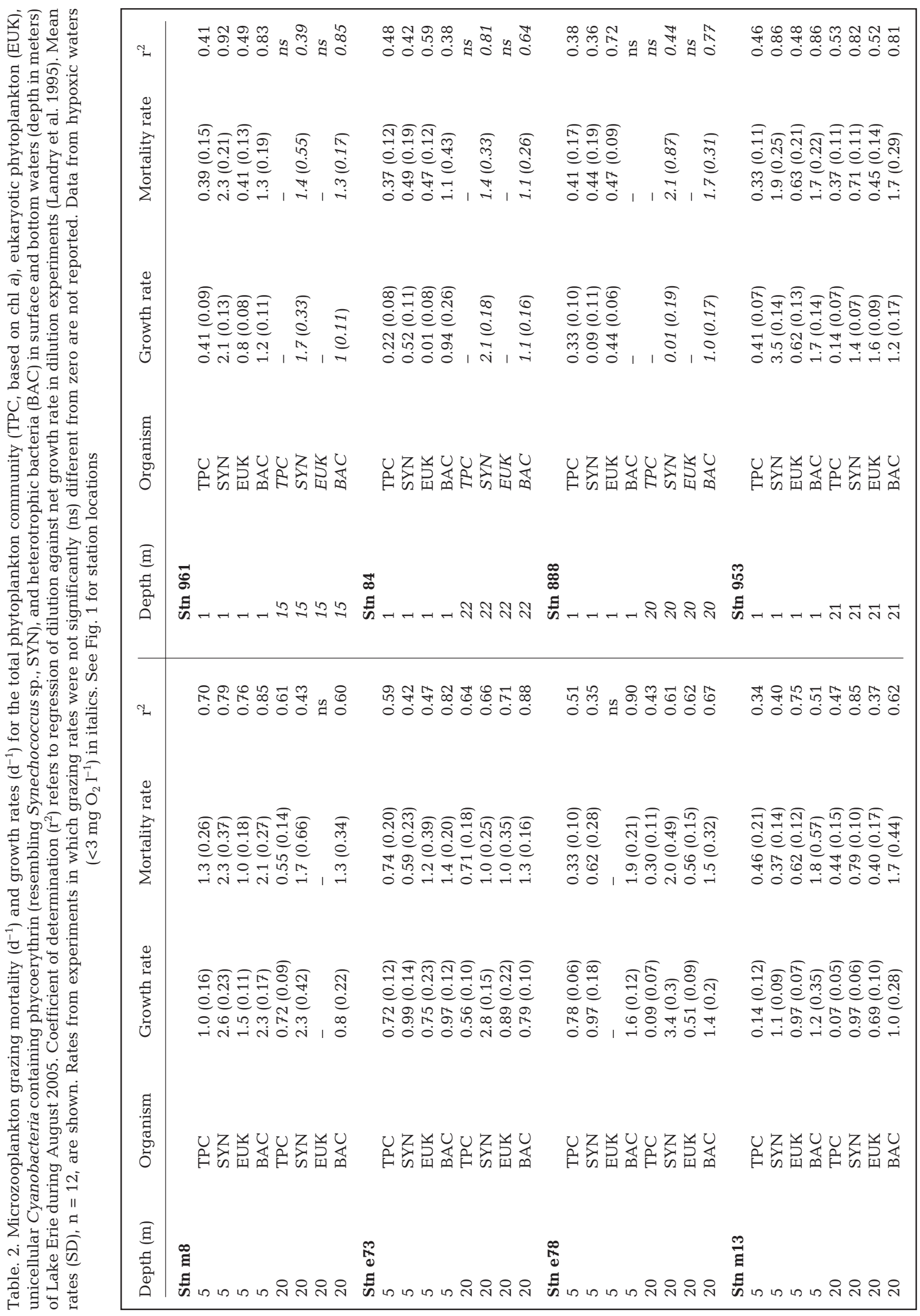


method. Grazing rates on picocyanobacteria and heterotrophic bacteria were measured in nearly all experiments (100 and 94\%, respectively, $\mathrm{n}=16$; Table 2); measurements were also made for the total phytoplankton community and eukaryotic algae in the epilimnion (100 and $87 \%$, respectively, $\mathrm{n}=8$; Table 2 ) and in the hypolimnion during early August (100 and 75\%, respectively, $\mathrm{n}=4$; Table 2 ) in most experiments. However, grazing impacts on the total phytoplankton community and on eukaryotic picoplankton were detected in the hypolimnion in only 1 of 4 experiments during late August, viz. at Stn 953, which had the highest bottom oxygen level at this time (Table 2).

\section{Bacterial mortality attributable to viruses}

The viral burst size of bacteria did not vary significantly with vertical space or time and averaged 14 VLP cell $^{-1}$ across sites and depths (Table 3). Although the percentage of virus infected bacteria decreased significantly from $5.3 \pm 2.8 \%$ in early August to $0.84 \pm 0.37 \%$ in late August (Mann-Whitney Rank Sum test, p < 0.001), this percentage did not change significantly with depth (Table 3). Percentage bacterial mortality attributable to viral lysis was significantly lower in epilimnion $(4.4 \pm 1.7 \%)$ than in hypolimnion waters (9.3 $\pm 3.9 \%$; Mann-Whitney Rank Sum test, $\mathrm{p}<0.001)$ (Table 3, Fig. 5). Across all sites, dates, and depths, viral lysis accounted for $7.7 \pm 4.0 \% \mathrm{~d}^{-1}$ of bacterioplankton mortality (Table 3).

\section{DISCUSSION}

\section{Dynamics of microbial populations}

Phototrophic (Fahnenstiel et al. 1998) and heterotrophic (Scavia \& Laird 1987) picoplankton constitute the majority of primary and secondary producers in the Great Lakes of North America. Consistent with these findings, the $<2 \mu \mathrm{m}$ plankton size fraction constituted $\sim 50 \%$ of total chl a (Table 1) and abundances of heterotrophic and autotrophic picoplankton populations persisted at $\sim 10^{6}$ and $10^{5}$ cells $\mathrm{ml}^{-1}$, respectively, in Lake Erie during this study (Table 1). The strong correlation between total chl $a$ and abundances of eukaryotic phytoplankton measured via flow cytometry (which quantified cells $<8 \mu \mathrm{m})(\mathrm{r}=0.82, \mathrm{p}<$

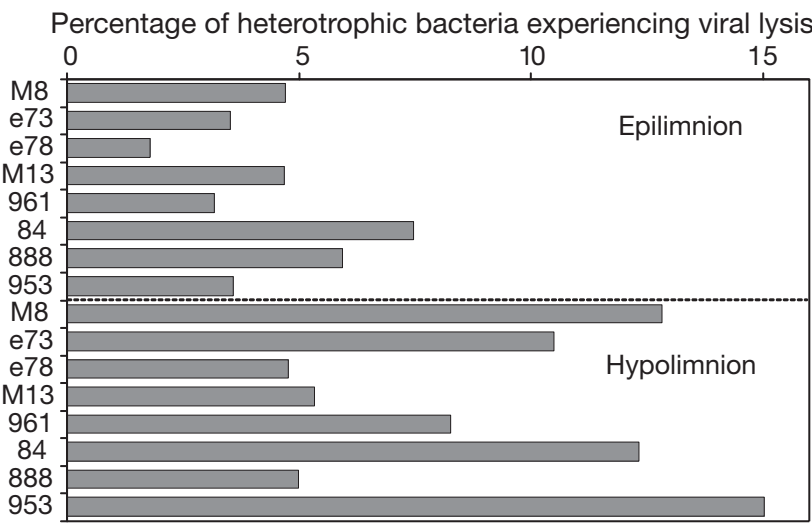

Fig. 5. Percentage of bacterial mortality attributable to viral lysis in surface and bottom waters of Lake Erie during August 2005. Mean relative SD of counts for all samples $=25 \%$. See Fig. 1 for sampling locations

0.0001) further confirms the notion that small phytoplankers comprise the majority of phytoplankton biomass in Lake Erie. With the majority of autotrophic and heterotrophic biomass made up of small plankton, mortality processes such as viral lysis and protistan grazing are bound to have a large impact on these communities and the Lake Erie food web in general.

During this study, Lake Erie bottom waters contained significantly lower eukaryotic phytoplankton

Table 3. Viral burst size, percentage of heterotrophic bacteria infected with virus-like particles, percentage of total mortality of heterotrophic bacteria attributable to viral lysis, and the rate of heterotrophic bacterial mortality (\% standard stock $\mathrm{d}^{-1}$ ) attributable to viral lysis in surface and bottom waters of Lake Erie during August 2005. Means (SD), $n=3$, are shown

\begin{tabular}{|cccccc|}
\hline \multirow{2}{*}{ Stn } & Depth $(\mathrm{m})$ & Burst size & \% infected & \% mortality & $\%$ mortality d \\
\hline M8 & 5 & $12(3.5)$ & $4.3(0.61)$ & $4.7(0.7)$ & $11(0.92)$ \\
& 20 & $17(8.0)$ & $10(5.4)$ & $13(7.9)$ & $10(0.38)$ \\
e73 & 5 & $13(4.2)$ & $3.3(0.2)$ & $3.5(0.23)$ & $4.5(0.77)$ \\
& 20 & $14(5.1)$ & $8.9(0.49)$ & $10(0.67)$ & $4.2(1.3)$ \\
e78 & 5 & $8.8 .(2.5)$ & $1.4(0.49)$ & $1.8(0.53)$ & $5.6(2.7)$ \\
& 20 & $17(11)$ & $4.4 .(2.2)$ & $4.8(2.7)$ & $15(7.3)$ \\
M13 & 5 & $23(3.3)$ & $4.3(2.3)$ & $4.7(2.6)$ & $2.2(0.69)$ \\
& 20 & $16(8.4)$ & $4.9(0.55)$ & $5.3(0.67)$ & $4.8(1.7)$ \\
961 & 1 & $15(5.1)$ & $0.42(0.34)$ & $3.2(2.6)$ & $9.0(3.2)$ \\
& 15 & $15(0.45)$ & $1.1(0.27)$ & $8.3(2.3)$ & $12(0.46)$ \\
84 & 1 & $12(1.7)$ & $0.94(0.76)$ & $7.5(6.4)$ & $5.6(1.8)$ \\
& 22 & $19(4.6)$ & $1.1(0.15)$ & $12(1.4)$ & $5.5(0.39)$ \\
888 & 1 & $15(4.6)$ & $0.77(0.40)$ & $5.9(3.2)$ & $4.3(0.69)$ \\
& 20 & $20(2.4)$ & $0.65(0.40)$ & $5.0(3.1)$ & $15(1.0)$ \\
953 & 1 & $10(0.81)$ & $0.48(0.28)$ & $3.6(2.2)$ & $5.4(2.0)$ \\
& 20 & $15(0.7)$ & $1.7(1.0)$ & $15(9.9)$ & $9.9(3.8)$ \\
Mean & & 15 & 3.2 & 6.7 & 7.76 \\
SD & & 3.8 & 3.1 & 4.1 & 3.99 \\
SE & & 0.95 & 0.76 & 1.0 & 1.00 \\
& & & & &
\end{tabular}


abundances and biomasses than surface waters. Growth rates of eukaryotic phytoplankton and the total phytoplankton community were significantly correlated with eukaryotic phytoplankton abundance and total phytoplankton biomass, respectively $(\mathrm{r}=0.72$, $\mathrm{p}<$ 0.001; $\mathrm{r}=0.57, \mathrm{p}<0.05)$. Eukaryotic phytoplankton abundance and biomass were also strongly and significantly correlated with dissolved oxygen concentrations $(\mathrm{r}=0.84, \mathrm{p}<0.0001 ; \mathrm{r}=0.75, \mathrm{p}<0.005)$. Hypolimnion hypoxia is an annual late summer occurrence in Lake Erie (Charlton 1980, Wilhelm et al. 2006). Our results suggest that decreased autotrophic growth rates and low photosynthetic oxygen production in bottom waters, likely due in part to low light levels, do not allow eukaryotic autotrophs to alleviate hypoxia during summer stratification.

Autotrophic and heterotophic plankton communities are closely associated in aquatic ecosystems; phytoplankton provide bacteria with organic carbon and bacteria regenerate inorganic nutrients that may promote primary production (Baines \& Pace 1991). Across all sites and depths, bacterial abundances were significantly correlated with levels of both eukaryotic algae and total chl a (p<0.004, r = 0.68; $\mathrm{p}<0.003, \mathrm{r}=0.67)$ and with the growth rates of the total phytoplankton community (as determined by dilution experiments, $\mathrm{r}=$ 0.81, $\mathrm{p}<0.0001)$. During periods of strong thermal stratification, this tight coupling may be explained by bacterial nutrient regeneration since summer growth rates of Lake Erie phytoplankton can be limited by phosphorus, iron, and nitrogen (North et al. 2007). Our observation of significantly enhanced phytoplankton growth rates upon the addition of nutrients during the majority of our dilution experiments (data not shown) further confirms the important role nutrient regeneration must play in this system.

\section{Grazing mortality of microbial populations}

This study provides evidence of the central role protistan grazing plays in the regulation and turnover of microbial populations in Lake Erie during summer. On average, grazing accounted for about half (40 to $50 \%$ ) of the daily mortality experienced by phytoplankton. These losses to herbivory are similar to those reported previously from other offshore (52 \pm $10 \%$, Twiss et al. 1996) and coastal locations (76\%, Lavrentyev et al. 2004) in Lake Erie, as well as coastal and oceanic ecosystems (41 to $47 \%$; Gobler et al. 2004, Calbet \& Landry 2004). In contrast to total phytoplankton, a much larger portion of the prokaryotic picoplankton populations (picocyanobacteria and bacteria) was consumed daily by microbial grazers (71 to $78 \%$ ). One Lake Erie study that attributed a portion of bacterivorous mortality to zooplankton (micro- and mesozooplankton grazing, Hwang \& Heath 1999) reported losses substantially lower (11 to $27 \%$ ) than ours, likely because that study (op. cit.) excluded from consideration nanoplankton grazers that typically dominate zooplankton grazing in aquatic ecosystems (Sherr \& Sherr 2002). However, in coastal Lake Erie, the impact of bacterivory has been shown to be similar to that measured in our study (70 to $90 \%$, Lavrentyev et al. 2004). In sum, our results suggest that protistan grazing was the primary source of mortality for eukaryotic and prokaryotic plankton in Lake Erie during periods of thermal stratification.

The abundance of ciliates, the dominant microzooplankton during this study, was consistent with earlier Lake Erie studies (Hwang and Heath 1997a, Fahnenstiel et al. 1998) and was significantly correlated with each of the potential prey items (total phytoplankton community [ch a]: $\mathrm{r}=0.64, \mathrm{p}<0.007$; eukaryotic algae: $\mathrm{r}=0.73, \mathrm{p}<0.002$; picocyanobacteria: $\mathrm{r}=0.68 \mathrm{p}<0.004$; heterotrophic bacteria: $\mathrm{r}=0.63$, $\mathrm{p}<0.009$ ), indicating a tight coupling of microbial predators and their prey in Lake Erie. Consistent with this observation, there was also a significant correlation between bacterial growth rates and bacterivory rates $(\mathrm{r}=0.66, \mathrm{p}<0.007)$. In the Great Lakes (Carrick et al. 1992, Lavrentyev et al. 1995, 2004) and elsewhere (Sherr \& Sherr 2002, Calbet \& Landry 2004), microzooplankton and HNF reproduction rates are equal to or even exceed those of their prey. This reproductive ability allows HNF to respond rapidly to changes in prey abundance (Miller et al. 1995), and partly accounts for such tight predator-prey couplings. Since planktonic production in the central basin of Lake Erie is strongly nutrient-limited during summer months (DeBruyn et al. 2004, North et al. 2007), tight predator-prey coupling is likely also influenced by protistan nutrient regeneration, which has been documented in the Great Lakes (Twiss et al. 1996, Gardner et al. 2004, Lavrentyev et al. 2004) and elsewhere (Nagata \& Kirchman 1992, Miller et al. 1995).

Although hypolimnion hypoxia is an annual late summer occurrence in Lake Erie (Charlton 1980), impacts of these events on microbial food web dynamics in this system are poorly understood. Hypoxic conditions cause significant reductions in the survival and growth of mesozooplankton (Roman et al. 1993, Richmond et al. 2006). However, some microzooplankton, including several ciliate species, can persist under hypoxic conditions in both marine (e.g. Setala 1991, Detmer et al. 1993) and freshwater systems (e.g. Bark \& Goodfellow 1985). During this study, both ciliate and rotifer abundances in waters with low dissolved oxygen concentrations $\left(<3 \mathrm{mg} \mathrm{l}^{-1}\right)$ were significantly lower 
$\left(6.2 \pm 1.0\right.$ ind $\left.\mathrm{ml}^{-1}\right)$ than in waters with higher oxygen content $\left(12 \pm 1.8\right.$ ind. $\mathrm{ml}^{-1}$ in water, DO $>3 \mathrm{mg} \mathrm{l}^{-1} ; \mathrm{p}<$ $0.05, t$-test). In addition, surface water overlying hypoxic bottom water had ciliate abundances (35 \pm 5.2 ind. $\mathrm{ml}^{-1}$ ) significantly higher than other surface waters $\left(12 \pm 1.5\right.$ ind. $\mathrm{ml}^{-1} ; \mathrm{p}<0.05, t$-test). For the entire study, ciliate abundance correlated significantly with dissolved oxygen concentrations ( $\mathrm{r}=0.58, \mathrm{p}<0.05$ ). While these differing patterns in ciliate and rotifer abundances might have been influenced directly by oxygen concentrations, there may also have been indirect influences since the abundance and biomass of algal prey items were also correlated with dissolved $\mathrm{O}_{2}$ concentration $(\mathrm{r}=0.84, \mathrm{p}<0.0001, \mathrm{r}=0.75, \mathrm{p}<0.005$, respectively).

Vertical changes in ciliate and rotifer abundances were paralleled by changes in detected herbivory, but not bacterivory. Significant rates of bacterivory were measured in every experiment, but grazing on eukaryotic phytoplankton and the total phytoplankton community (chl a) was undetectable during 3 experiments in which ambient dissolved oxygen was $<3 \mathrm{mg} \mathrm{l}^{-1}$ (Table 2). In contrast, significant rates of grazing on picoeukaryotic algae and total phytoplankton (chl a) were measured in all other experiments (Table 1), suggesting that the significant reduction in ciliate and rotifer grazer abundance in hypoxic bottom waters of Lake Erie (Fig. 3) was associated with a disruption in microzooplankton herbivory. Alternatively, it is possible that the absence of herbivory in deep hypoxic waters may be related in part to lower abundances of eukaryotic algal prey $\left(<10^{3}\right.$ cells $\mathrm{ml}^{-1}$, Table 1$)$, although densities in these waters were not significantly different from deep, oxic waters. In contrast to herbivory, the persistence of bacterivory in hypoxic waters indicates a shift in microbial food web structure whereby herbivores moved out of hypoxic waters (and potentially entered surface waters, Fig. 3), while bacterivorous species were unaffected by hypoxia and continued to graze on prokaryotes at a significant rate. This observation is supported by a significant correlation between grazing rates on picocyanobacteria and the abundance of HNF $(\mathrm{r}=0.53, \mathrm{p}<0.05)$, but not other grazers. Moreover, abundances of HNF in hypoxic waters were not significantly different from those in oxygenated water masses across the entire data set, despite some distinct vertical variability in late August (Fig. 3). Due to the disruption in herbivory, which occurred in concurrence with a significant reduction in ciliate and rotifer abundances, we hypothesize that these microzooplankters are the dominant herbivores in the hypolimnion of Lake Erie and that HNF, whose abundances were not correlated with oxygen concentrations (Fig. 3) but were significantly correlated with grazing rates on picocyanobacteria, are the primary bacterivores in a hypoxic hypolimnion.

\section{Viral lysis of heterotrophic bacteria and potential interaction with grazers}

During this study, $7.7 \pm 1.0 \%$ of bacterial stocks, on average, were lysed per day by viruses, reaching as high as $15 \%$ in some instances (Table 3 ). These percentages are slightly lower than those reported previously for Lake Erie (17 to $23 \%$, Wilhelm \& Smith 2000) but are within the range of bacterial mortality attributed to viral lysis in other aquatic ecosystems (Wilhelm \& Suttle 1999). During thermal stratification in Lake Erie, there was a significant inverse correlation between bacterial growth rates and percentage of bacterial mortality due to viruses $(\mathrm{r}=-0.51, \mathrm{p}<0.05)$, and a significant inverse correlation between bacterial abundance and viral burst size in bacteria $(\mathrm{r}=-0.53$, $\mathrm{p}<0.05)$. Hence, while the percentage of total mortality due to viral lysis was small, this process seems to have a discernible impact on bacterial growth and abundance in Lake Erie.

The combination of our assessments of viral lysis and bacterivory in Lake Erie during thermal stratification indicates that nearly the entire bacterial population $(85 \%)$ is turned over daily at this time. To our knowledge, this is the first study to simultaneously assess the effects of both viral lysis and bacterivory as sources of bacterial mortality in the Great Lakes. In a coastal marine ecosystem, Fuhrman \& Noble (1995) suggested that viruses and microzooplankton grazing contributed equally toward the nearly $100 \%$ daily turnover of bacteria, while other aquatic studies have reported close to $100 \%$ turnover of bacteria with a higher percentage of mortality attributed to zooplankton than viruses (Bettarel et al. 2003, Choi et al. 2003, Jacquet et al. 2005). Regardless of any detailed differences from other works, our results demonstrate the critical roles viruses and bacterivorous protists play in regulating populations of heterotrophic bacteria in Lake Erie.

Viral mortality of bacteria in the epilimion was significantly lower than in the hypolimnion (Fig. 5), and there was a significant inverse correlation between viral mortality and levels of dissolved oxygen ( $\mathrm{r}=$ $-0.54, \mathrm{p}<0.05)$. These results are consistent with those of Weinbauer \& Höfle (1998), who detected higher rates of viral mortality in the hypolimnion than in surface water. Viruses can be deactivated by UV radiation in surface waters of aquatic ecosystems (Wilhelm et al. 1998), which may account for reduced viral abundances in shallow layers (Wilhelm et al. 2003) and perhaps for the lower levels of viral mortality in bacteria in 
surface waters than in the hypolimnion. Higher rates of viral lysis in the hypolimnion may also enhance dissolved organic matter production (Gobler et al. 1997), which in turn may stimulate the growth of uninfected heterotrophic bacterioplankton (Noble et al. 1999) and potentially increase oxygen consumption rates. However, assuming a bacterial C content of $20 \mathrm{fg} \mathrm{cell}^{-1}$ (Lee \& Furhman 1987) and a mean bacterial standing stock of $6.2 \times 10^{8} 1^{-1}$ (Table 1 ), the daily viral lysis of $10 \%$ of the bacterial community per day in the hypolimnion (Table 3) over the 3 mo period of stratification (Wilhelm et al. 2006) would release only enough $C$ to cause an oxygen demand of $\sim 0.1 \mathrm{mg} \mathrm{l}^{-1}$.

Finally, it is plausible that the prevailing hypoxic conditions in Lake Erie's hypolimnion during late summer and early fall may facilitate interactions and feedback among viruses, grazers and bacterial populations. In some freshwater systems, rates of viral infection of bacteria can increase in the presence of enhanced flagellate bacterivory (Šimek et al. 2001, Weinbauer et al. 2007). As such, the shift in hypolimnion grazing during hypoxia towards a dominance of bacterivory may, in turn, promote viral infection and lysis of bacterial populations (Šimek et al. 2001, Weinbauer et al. 2007). If this does occur, it may also create a positive feedback loop with summer hypoxia enhancing bacterivory, which enhances viral lysis, both of which could promote bacterial oxygen consumption and further promote hypoxia.

Acknowledgements. This research was supported by awards from NOAA's Great Lakes Environmental Research Laboratory's 2005 International Field Year for Lake Erie, an award from New York Sea Grant, and NSF awards DEB-0129118 and MCB-0239997. We thank the captain and crew of the Canadian Coast Guard Vessel 'Limnos' and the RV 'Lake Guardian' for logistical support and assistance during cruises.

\section{LITERATURE CITED}

Baines SB, Pace ML (1991) The production of dissolved organic carbon by phytoplankton and its importance to bacteria - patterns across marine and fresh-water systems. Limnol Oceanogr 36:1078-1090

Bark AW, Goodfellow JG (1985) Studies on ciliated protozoa in eutrophic lakes. 2. Field and laboratory studies on the effects of oxygen and other chemical gradients on the ciliate distribution. Hydrobiologia 124:167-188

Bettarel Y, Amblard C, Sime-Ngando T, Carrias JF, Sargos D, Garabetian F, Lavandier P (2003) Viral lysis, flagellate grazing potential, and bacterial production in Lake Pavin. Microb Ecol 45:119-127

Binder B (1999) Reconsidering the relationship between virally induced bacterial mortality and frequency of infected cells. Aquat Microb Ecol 18:207-215

Calbet A, Landry MR (2004) Phytoplankton growth, microzooplankton grazing, and carbon cycling in marine systems. Limnol Oceanogr 49:51-57
Carrick HJ, Fahnenstiel GL, Taylor WD (1992) Growth and production of planktonic protozoa in Lake Michigan: in situ and in vitro comparisons and importance to food web dynamics. Limnol Oceanogr 37:1221-1235

Charlton MN (1980) Oxygen depletion in Lake Erie: Has there been any change? Can J Fish Aquat Sci 37:72-81

$>$ Choi DH, Hwang CY, Cho BC (2003) Comparison of virusand bacterivory-induced bacterial mortality in the eutrophic Masan Bay, Korea. Aquat Microb Ecol 30: $117-125$

Colombet J, Sime-Ngando T, Cauchie HM, Fonty G, Hoffmann L, Demeure G (2006) Depth-related gradients of viral activity in Lake Pavin. Appl Environ Microbiol 72: $4440-4445$

DeBruyn JM, Leigh-Bell JA, McKay RML, Bourbonniere RA, Wilhelm SW (2004) Microbial distributions and the impact of phosphorus on bacterial activity in Lake Erie. J Gt Lakes Res 30:166-183

Detmer AE, Giesenhagen HC, Trenkel VM, Auf dem Venne H, Jochem FJ (1993) Phototrophic and heterotrophic picoand nanoplankton in anoxic waters of the central Baltic Sea. Mar Ecol Prog Ser 99:197-203

Fahnenstiel GL, Krause AE, McCormick MJ, Carrick HJ (1998) The structure of the planktonic food-web in the St. Lawrence Great Lakes. J Gt Lakes Res 24:531-554

Fuhrman JA, Noble RT (1995) Viruses and protists cause similar bacterial mortality in coastal seawater. Limnol Oceanogr 40:1236-1242

Gardner WS, Lavrentyev PJ, Cavaletto JF, McCarthy MJ, Eadie BJ, Johengen TH, Cotner JB (2004) Distribution and dynamics of nitrogen and microbial plankton in southern Lake Michigan during spring transition 1999-2000. J Geophys Res 109(C3):C03007

Gobler CJ, Hutchins DA, Fisher NS, Cosper EM, SañudoWilhelmy SA (1997) Cycling and bioavailablity of C, N, P, $\mathrm{Fe}$ and Se released by viral lysis of a marine chrysophyte. Limnol Oceanogr 42:1492-1504

Gobler CJ, Deonarine SN, Leigh-Bell J, Downes Gastrich M, Anderson OR, Wilhelm SW (2004) Ecology of phytoplankton communities dominated by Aureococcus anophagefferens: the role of viruses, nutrients, and microzooplankton grazing. Harmful Algae 3:471-483

Hasle GR (1978) The inverted microscope method. UNESCO Monogr Oceanogr Method 6:88-96

> Hwang SJ, Heath RT (1997a) The distribution of protozoa across a trophic gradient, factors controlling their abundance and importance in the plankton food web. J Plankton Res 19:491-518

> Hwang SJ, Heath RT (1997b) Bacterial productivity and protistan bacterivory in coastal and offshore communities of Lake Erie. Can J Fish Aquat Sci 54:788-799

$>$ Hwang SJ, Heath RT (1999) Zooplankton bacterivory at coastal and offshore sites of Lake Erie. J Plankton Res 21: $699-719$

Jacquet S, Domazon I, Personnic S, Ram ASP, Hedal M, Duhamel S, Sime-Ngano T (2005) Estimates of protozoanand viral-mediated mortality of bacterioplankton in Lake Bourget (France). Freshw Biol 50:627-645

> Jochem FJ (2001) Morphology and DNA content of bacterioplankton in the northern Gulf of Mexico: analysis by epifluorescence microscopy and flow cytometry. Aquat Microb Ecol 25:179-194

Johannsson O, Dermott R, Graham DM, Dahl JA, Millard ES, Myles DD, LeBlanc J (2000) Benthic and pelagic secondary production in Lake Erie after the invasion of Dreissena spp. with implications for fish production. J Gt Lakes Res 26:31-54 
Landry MR, Kirshtein J, Constantinou J (1995) A refined dilution technique for measuring the community grazing impact of microzooplankton, with experimental tests in the central equatorial Pacific. Mar Ecol Prog Ser 120: $53-63$

Lavrentyev PJ, Gardner WS, Cavaletto JF, Beaver JR (1995) Effects of the zebra mussel (Dreissena polymorpha Pallas) on protozoa and phytoplankton in Saginaw Bay, Lake Huron. J Gt Lakes Res 21:545-557

Lavrentyev PJ, McCarthy MJ, Klarer DM, Jochem FJ, Gardner WS (2004) Estuarine microbial food web patterns in a Lake Erie coastal wetland. Microb Ecol 48:567-577

Lee S, Fuhrman J (1987) Relationships between biovolume and biomass of naturally derived marine bacterioplankton. Appl Environ Microbiol 53:1298-1303

Miller CA, Penry DL, Glibert PM (1995) The impact of trophic interactions on rates of nitrogen regeneration and grazing in Chesapeake Bay. Limnol Oceanogr 40:1005-1011

Nagata T, Kirchman DL (1992) Release of macromolecular organic complexes by heterotrophic marine flagellates. Mar Ecol Prog Ser 83:233-240

Noble RT, Middelboe M, Fuhrman JA (1999) Effects of viral enrichment on the mortality and growth of heterotrophic bacterioplankton. Aquat Microb Ecol 18:1-13

North RL, Guildford SJ, Smith REH, Havens SM, Twiss MR (2007) Evidence for phosphorus, nitrogen, and iron colimitation of phytoplankton communities in Lake Erie. Limnol Oceanogr 52:315-328

Olson RJ, Zettler ER, Chisholm SW, Dusenberry JA (1991) Advances in oceanography through flow cytometry. In: Demers S (ed) Particle analysis in oceanography. Springer-Verlag, Berlin, p 351-399

Proctor LM, Okubo A, Fuhrman JA (1993) Calibrating estimates of phage-induced mortality in marine bacteria: ultrastructural studies of marine bacteriophage development from one-step growth experiments. Microb Ecol 25:161-182

Reckermann M, Veldhuis MJW (1997) Trophic interactions between picophytoplankton and micro- and nanozooplankton in the western Arabian Sea during the NE monsoon 1993. Aquat Microb Ecol 12:263-273

Richmond C, Marcus NH, Sedlacek C, Miller GA, Oppert C (2006) Hypoxia and seasonal temperature: short-term effects and long-term implications for Acartia tonsa Dana. J Exp Mar Biol Ecol 328:177-196

Roman MR, Gauzens AL, Rhinehard WK, White JR (1993) Effect of low oxygen waters on Chesapeake Bay zooplankton. Limnol Oceanogr 38:1603-1614

Scavia D, Laird GA (1987) Bacterioplankton in Lake Michigan: dynamics, controls, and significance to carbon flux. Limnol Oceanogr 32:1017-1033

Scavia D, Lang GA, Kitchell JF (1988) Dynamics of Lake Michigan plankton: a model evaluation of nutrient loading, competition and predation. Can J Fish Aquat Sci 45: 165-177

Setala O (1991) Ciliates in the anoxic deep-water layer of the Baltic. Arch Hydrobiol 122:483-492

Editorial responsibility: Urania Christaki, Wimereux, France
Sherr EB, Sherr BF (2002) Significance of predation by protists in aquatic microbial food webs. Antonie Leeuwenhoek 81:293-308

Sherr EB, Caron DA, Sherr BF (1993) Staining of heterotrophic protists for visualization via epifluorescence microscopy. In: Kemp PF, Sherr BF, Sherr EB, Cole JJ (eds) Aquatic microbial ecology. Lewis Publishers, Boca Raton, FL, p 213-227

Šimek K, Pernthaler J, Weinbauer MG, Hornak K and others (2001) Changes in bacterial community composition and dynamics and viral mortality rates associated with enhanced flagellate grazing in a mesoeutrophic reservoir Appl Environ Microbiol 67: 2723-2733

Twiss MR, Campbell PGC, Auclair JC (1996) Regeneration, recycling, and trophic transfer of trace metals by microbial food-web organisms in the pelagic surface waters of Lake Erie. Limnol Oceanogr 41:1425-1437

> Weinbauer MG, Höfle MG (1998) Significance of viral lysis and flagellate grazing as controlling factors of bacterioplankton production in a eutrophic lake. Appl Environ Microbiol 64:431-438

Weinbauer MG, Suttle CA (1996) Potential significance of lysogeny to bacteriophage production and bacterial mortality in coastal waters of the Gulf of Mexico. Appl Environ Microbiol 62:4374-4380

Weinbauer MG, Winter C, Höfle MG (2002) Reconsidering transmission electron microscopy based estimates of viral infection of bacterioplankton using conversion factors derived from natural communities. Aquat Microb Ecol 27: 103-110

Weinbauer MG, Hornak K, Jezbera J, Nedoma J, Dolan JR, Šimek K (2007) Synergistic and antagonistic effects of viral lysis and protistan grazing on bacterial biomass, production and diversity. Environ Microbiol 9: $777-788$

Welschmeyer NA (1994) Fluorometric analysis of chlorophyll $\mathrm{a}$ in the presence of chlorophyll b and pheopigments. Limnol Oceanogr 39:1985-1992

- Wilhelm SW, Smith REH (2000) Bacterial carbon production in Lake Erie is influenced by viruses and solar radiation. Can J Fish Aquat Sci 57:317-326

Wilhelm SW, Suttle CA (1999) Viruses and nutrient cycles in the sea. Bioscience 49:781-788

Wilhelm SW, Weinbauer MG, Suttle CA, Jeffrey WH (1998) The role of sunlight in the removal and repair of viruses in the sea. Limnol Oceanogr 43:586-592

Wilhelm SW, Jeffrey WH, Dean AL, Meador J, Pakulski JD, Mitchell DL (2003) UV radiation induced DNA damage in marine viruses along a latitudinal gradient in the southeastern Pacific Ocean. Aquat Microb Ecol 31:1-8

Wilhelm SW, Bullerjahn GS, Eldridge ML, Rinta-Kanto JM, Poorvin L, Bourbonniere RA (2006) Seasonal hypoxia and the genetic diversity of prokaryote populations in the central basin hypolimnion of Lake Erie: evidence for abundant cyanobacteria and photosynthesis. J Gt Lakes Res 32:657-671

Submitted: August 16, 2007; Accepted: February 14, 2008 Proofs received from author(s): April 16, 2008 